\title{
NEW 19TH CENTURY DEFENSIVE ARCHITECTURAL CONTRIBUTIONS IN EGYPT: THE BASTION SYSTEM (HISTORICAL AND ARCHAEOLOGICAL CONSIDERATIONS)
}

\author{
Abdelwahab. M. \\ Islamic Archaeology dept, Faculty of Archaeology, Fayoum Univ., Fayoum, Egypt \\ E-mail address:maa02@fayoum.edu.eg
}

\begin{tabular}{l}
\hline Article info. \\
\hline Article history: \\
Received: $1-9-2020$ \\
Accepted: $15-6-2021$ \\
Doi: 10.21608 /ejars.2021.179499
\end{tabular}

Keywords:

Bastion system

Fortification

Mehmet' Ali

Military architecture

Defensive system

\begin{abstract}
EJARS - Vol. 11 (1) - June. 2021: 87-100
Abstract:

Impressive fortification and renovation work was carried out in Egypt in Mehmet 'Ali's reign (1805-1848); the pasha rebuilt the old fortifications, and erected new forts according to the new developments of weapons and defensive systems. So, he recruited the European scientific and military cadres to seeking their services. Therefore, the military architecture of his reign was distinguished with the European influences from Turkey, Italy, France and Albania. In other words, many new and uncommon architectural elements have imported to the Egyptian military architecture in the first of $19^{\text {th }}$ century. The innovation introduced into military architecture by Mehmet 'Ali is the regular designs of the external and internal lines of the buildings, and the types of the towers to be compatible with attack and defensive weapons. This new type of military architecture was called the bastion system. The article's primary purpose is discussing: the universal features of military fortifications of $19^{\text {th }}$ century in Egypt by tracing the European influences and follows the origins of the fortification designs of Mehmet' Ali which so-called the bastion system. These fortifications carried out some relations on structure, designs, plans, and elements belonged to the prototypes of the European styles, like the Venetian, Ottoman and Frankish styles which transformed directly and indirectly by Mehmet 'Alito Egypt in the beginning of the $19^{\text {th }}$ century. The study willed fine the types of the most important military architectural designs dating back to the nineteenth century in Egypt and tracing its origins in Europe. Also will enumerate the channels which imported this new technology and architectural features to Egypt and investigating the factors which had been arrived from deferent European sources, such as the raise and the personal vision of Mehmet 'Ali, the educational missions to European countries, the European scientific and military cadres and the field experiences of the Pasha in the deferent countries of Ottoman Empire.
\end{abstract}

\section{Introduction}

The literature sources and the archaeological remains alike contain a real wealth of information on the military architecture of Mehmet 'Ali and many academic studies have been focus on his fortifications in Egypt. For the authors of two publications on the subject in Arabic, Al-Rajabi wrote a monograph with photographs investigated in 1997 [1]. His purpose was deals with the most important architectural works and the history of Mehmet 'Ali. As well as the history of Al-Jabarti [2] who cared about listing some architectural details in this reign. Also, the orientalists were interested with the architectural development in Egypt, such as the example of Wiet [3], Mantel [4]. Furthermore, there are many Arabic studies on the subject: like Mahfouz, 
who focused on military buildings in Cairo [5] such as Al-Muqattam and Salah alDin castles in the reign of Mehmet 'Ali as the military architecture in northern Egypt, Darwish [6] addressed the forts and castles in the city of Rosseta, in which he focused on the most important architectural elements developed in the era of Mehmet 'Ali. The study of the $19^{\text {th }}$ fortifications in Egypt constitutes a part of the broader topic of the European fortifications and defensive system. The majority of the current studies dealing particularly with the Egyptian military in Mamluk and Ottoman periods, without focusing on the architectural development of using the bastions as a direct response to the requirements of weapon technology. The previous studies did not dedicate a comprehensive study to many of the architectural elements imported from the Europe to Egypt in the reign of Mehmet 'Ali, which came within the organized trend of Mehmet 'Ali to modernize the defensive and offensive systems of the modern Egyptian army. This paper focuses on one of the most important elements coming to Egypt as a harmonization of technological advances by using modern artillery. The reign of Mehmet 'Ali Pasha [7-9] started in 1805 as Wâli after he was appointed by the Sultan of Ottomans and ended in 1848. In few decades the Pasha had taken different radical measures to change the position of his province within the Empire in all fields; economic, social, culture, education and military force. He aims to make Egypt controller of the traditional borders of Egypt includes Sudan, Greece (Crete-Morea), Anatolia, Hijas, Syria [10]. The new ruler has succeeded in exploiting Egyptian capabilities and managing state resources in order to achieve a goal in building a strong state ruled by him and his elite [11]. While the pasha planned his new military forces, the Imperial army of Ottoman model was not far from his mind. For soon after commanding Suleiman pasha (Seves) [5,8] and Mohamed Lazuglo to continue their mission, Mehmet 'Ali ordered his son Ibrahim to adopt the official stru- cture of the Ottoman army in the reign of Sultan Selim III (1789-1807) ${ }^{\text {(a) }}$. Although the composition of the army set by Suleiman Pasha the French commander was very practical and Ibrahim Pasha was convinced of its implementation, Mehmet 'Ali preferred the model of the Ottoman army ${ }^{(b)}$ [5], the Pasha explained to his leaders and his son; "it is similar to the one Napoleon had used to lead an army composed of several thousand troops. Our army however, is a new and much smaller one and we have only recently begun to create it" [10]. The classical style of Mamluk and Ottoman military architecture were domain Egypt till the beginning of $19^{\text {th }}$ with some renovations and new architectural designs from the Western Europe to the Ottoman military architecture, were imported to Egyptian fortification system [12]. In a few decades, Mehmet 'Ali created a formidable network of fortifications, the new and the old fortresses in Cairo and Alexandrea formed the corner stone and the back bone of his defense lines; these were renovated and some of strongholds were built additionally. The Egyptian defensive system before $19^{\text {th }}$ century was composed of; the gates, towers and some defensive palisades by definition are parts of enceintes or enclosure. But after that the historians of the Western military refers to the fortification consist of defensive palisades, ramparts, walls as curtains which were fronted by moats or ditches [13]. The curtains act as extensions of the shield and protecting the defenders against the weapons of them attackers [14]. The very important part of these fortifications is the external projections of a barrier and star forts ${ }^{(c)}$ [15] with the bastions; it is large enough to hold large number of defenders and weapons. Their purpose as mentioned; is to inflict flanking fire on any attackers closely approaching the curtains and adjacent bastions [13,16], fig. (1). Very quickly with the development of firearms and fortifications, bastions style which its function was to direct fire against enemies [16] became obsolete and had to be rebuilt [17] and it can be said that; these military principles and requir- 
ements were very clear in the mind of Mehmet 'Ali, the founder of the modern Egyptian army. So, the primary goal is revealing the architectural origins of the bastion and it characteristics, which came from Europe to the military architecture in Egypt during the French campaign against Egypt (1798-1011) [6] and became the distinctive architectural component of the military architecture in the era of the Mehmet 'Ali since 1805.

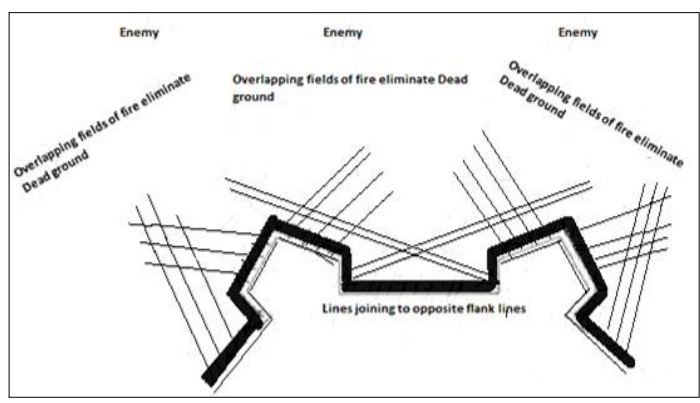

Figure (1) Shows the bastion system which achieved a perfect side protection and coverage to the blind angles and allows the defense of curtain walls (after, Ioanas, 2018)

\subsection{The definition of bastion}

Fortifications have been a part of the defense of cities and towns for millennia. By the time, it became increasingly effective to meet the different threats and the developments of weapons which proved that the older fortifications comparatively became useless [18]. The new technology of the firearms not only affected the fundamentals of warfare but also triggered a revision of the regulations of medieval military architecture [19]. It was obvious that the military defenses should be designed according to the developments of the firearms which made the fortress considered as a place for attacking and offensive actions, not only for defensive actions, where the troops within can control the outside areas. Thus, it could be define the bastion or bulwark as an external projection engaged to an external curtain wall, most usually angular in form located in the corners, and it is large enough to have many defenders and their fire weapons [16], as a direct response to the development of artillery in the middle Ages. The final developed bulwark consists of two flanks and two faces protecting adjacent bastions and the curtain walls to inflict flanking fire on the enemies [20].

\subsection{The architectural origins of the bastion}

The processes of state formation and concurrent changes in warfare, mostly the requirements to development of the new system of fortifications, greatly increased needs for architects to devise an adequate fortifications and military architecture response to the technology of heavy artillery [21]. So, architects should promote and develop some novel designs that could withstand the new technology; these fortresses are so called trace italienne $e^{(\mathrm{d})}$ [18-22], which have many bastions in the corners. The literature sources refers that there are two theories about the origins of bastion design:

\subsubsection{The first theory}

Some authors [23] believe that it was seen for the first time in mid- $15^{\text {th }}$ century. During the $2^{\text {nd }}$ half of the $15^{\text {th }}$ and beginning of $16^{\text {th }}$ centuries. The bastion fortifications were developed primarily by Italian architects [21] against the French conquest of Italian lands with new artillery (1494-1559). This Italian style is an accurate translation of designs of Francesco di Giorgio Martini (1439-1501) $)^{(\mathrm{e})}$ [23] who in his treatise; civil and military architecture (Architetturacivile e militare), supported an idea based on the widespread possession of cannon, fig. (2). His bastions are imperfect, in the bases of the round towers are not well covered by enfilading fire from other points. The new principles fully elaborated in Italy by the middle of $16^{\text {th }}$ century, and derived from elementary geometry, are elaborately treated. The engineer had to learn to set out the angles, slopes, and sides exactly to obtain the required protection [24]. The Italian military Engineers took up the ingenious and perennial challenge with attach and defense systems, and use the concept of Aristotle by which; " just as assailants are concerned with finding the means to prevail, so also those who defend themselves have found 
some and must find and devise others" $[17,25]$. So for the protection and wellbeing of the states, it was important to design the bastion, to replace the fortifications with the huge thickness of walls, which were not even this enough. From here; the military architects have proposing many new defensive designs [17]. Between 1540 and 1570, the architects were heavily in demand throughout Europe to help and supervision the new fortifications; replacing obsolete medieval city walls with bastion style fortifications. The Italian architects have introduced the new defensive system in Europe [21].

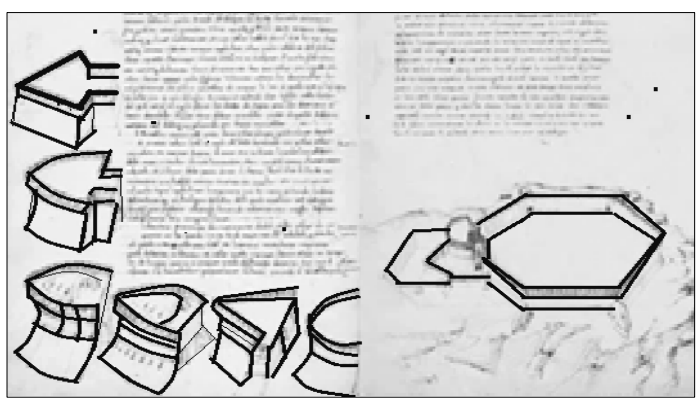

Figure (2) Shows the basic example of angled bastions by architect Francesco di Giorgio Martini, Treatise on Architecture, National Central Library of Florence (after, Robert, 2013)

\subsubsection{The second theory}

It. suggests the Ottoman origins of the polygons forts and bastion design, which was moved to Italy by architects whom lived in Constantinople in $15^{\text {th }}$ century. Where it adopts this trend; that the Romans and Greeks were not the only influence on the Renaissance military architects; the Ottoman military architects also influenced the Italian engineers in the scientific and geometric layout of a fortification when they were traveled to Constantinople Based on an invitation of Emperor Mehmed II [14]. And the fist examination of this new concept or method was the Rumeli Hisar $1452[26,27]$. Also this theory is based on the general similarity in the engineering principles used in the castles of Jalal alDin, Kilid Bar and Kasr al-Tina $\left(14^{\text {th }}-\right.$ $15^{\text {th }}$ centuries) and the castle trace Italienne with five angled bastions on each corner, fig. (3) $[18,28]$. According to the first theory; the first clear example of the pentagonal bastion could be seen in The
Maddalene Bastionin Verona (1527), which designed by Sanmicheli ${ }^{(f)}$ [29]. Immediately the new designs were found great acceptance by Venetians and have been separated to entirely Europe especially in the East which concerned with the necessity of operations to defend its property against the Turkish attacks [18]. These similarities of geometric designs prove that there was free exchange of scientific ideas between the architects of the West and East in this period. Thus, it is important to note that the overall layouts of the geometric or bastion fortifications were not a new invention of the Italian architects. This, too, was transferred from the practices of the Ottoman fortification architects and their creation of a geometric, scientific layout.

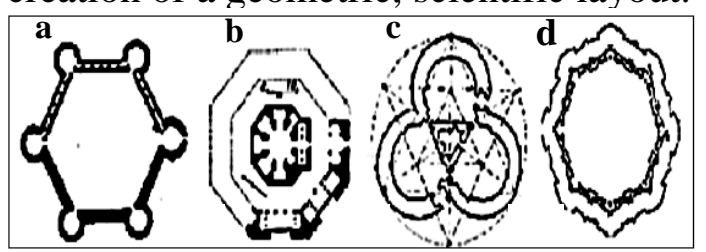

Figure (3) Shows the early Ottoman bastions which affected the European architect's designs trace italienne style in $14-15^{\text {th }}$ centuries (after, Robert, 2013), a. a layout of Jalal al-Din castle, $\underline{\mathbf{b}}$. a layout of Kasr al-Tina, c. a layout of Kilid Bar, $\underline{\text { d. }}$ a layout of a trace Italienne

\subsection{The principles of the functional aspects of the bastion}

The fundamental feature of the new system -bastion- of constructions was; "the relationship between its parts is comparable to that of the component parts of a geometric design" [17]. For this; any deference affects the whole as in the geometric continuum of the perspective and The connect between the bastions and the curtain walls allow the cannons to eliminate the blind points and offer only an oblique and not frontal exposure to attacking fire, deviating its direction and dampening the dynamic force [17]. Thus, the so-called bastioned form as a geometric design it was shaped a continuous system and was very appropriate, especially when compared to the artillery bases used at the time because this system has no any blind points or angles [18]. The previous rounded shape which had been dominant the defensive designs in the mediaeval ages, created "dead zones" which 
were comparatively hidden from cannon's fire, because the open direct angles from external area outside the walls. To estop these old shapes had extended into pentagonal shape which deleted the blind points of the towers, fig. (4-a), it allow for a perfect firing lines, depending on the basics of side defense, attack and coverage [17]. Based on innovations; the new system was a unified ensemble, in which the design, shape and dimensions of every fortification unit had specific geometrical relation with entire construction [25], fig. (4-b). By comparative study to the design of the round tower and the bastion design; the bastion with its polygons dose not leave uncovered parts or blind angles thanks to its shape [30], and contain a greater number of gun positions to more cannons. While the round towers have many blind points. The special feature of bastion system is the flanking coverage to the adjacent bastions. This gave rise to the so-called bastioned front, conceived according to formal rules and geometric ratios and refined on the basis of the range of the artillery in use [17], and gave rise to the bastion bloc, designed according to geometric proportion and repeated on the roles of the standard and the domain filed of the artillery in use [14]. This new design was known as the bastion or pentagonal structures, achieved these goals and protected all the points of the curtain, especially these bastions were armed with powerful artillery that shooting sideways at the infantry of the attackers attempting to pass through the gap [16].

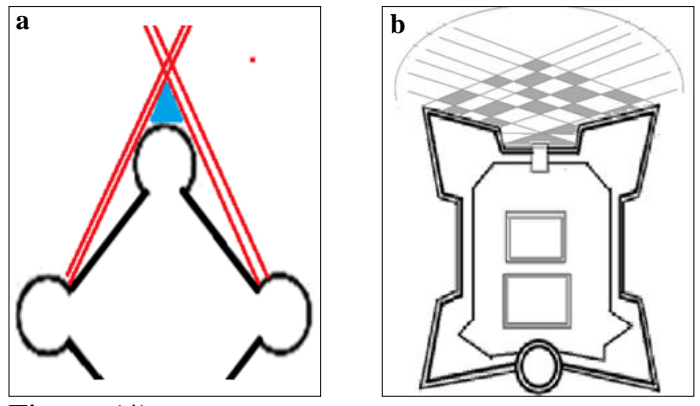

Figure (4) Shows ‥ depiction of dead areas in front of the round towers (after, John Lynn, 1969), b. the angled bastions with loopholes from which archers, gunners and artillerymen could fire from a hidden positions and extend covering fire for the adjacent tower of Mehmet 'Ali's castle (after, Mahfouz, 1999)

\section{The Case Study}

\subsection{The contributions of military arc- hitecture by Mehmet 'Ali}

It was necessary to Mehmet 'Ali to adopt a military architectural policy based on the latest warfare systems. Hehad decided from the first time to develop and implement this architectural policy and the military architecture of Mehmet 'Ali was distinguished by the appearance of many Western elements, which have been separated, which were not common in their counterparts before in Egypt such as the so-called bastions. Mehmet 'Ali's fortifications in Cairo and the northern coast consider a part of the broader of the military architecture and defensive system in Egypt. Within a few decades, he had erected a formidable lines and networks of forts in Egypt especially in Cairo and Alexandria. The reusing previous fortresses were very important for the Pasha's defense lines, these were renovated, but the backbones of these renovations were the new fortresses which were erected from 1805. And the archaeological sources and the written studies alike contain a wealth of information on these constructions of defensive projects of Mehmet 'Ali in Egypt $[5,7,31]$ proves his huge efforts in this filed. But there is an urgent question about the channels which have transformed this new technology and architectural features to Egypt. It could be said that; there were many factors affected the Egyptian military of Mehmet 'Ali, these factors had been transformed from deferent channels, through which European influences in general and Ottoman in particular moved to the new state of Mehmet 'Ali. It could be said that; Mehmet 'Ali's personal vision and his European intellectual convictions was the essential channel through which European and Ottoman influences were transferred to the Egyptian army and military fortifications he established to defend his independence country. That vision stems from his European and military upbringing, as his birthplace Kavala was one of the Ottoman cities more than three centuries ago. With his military experience, Mehmet 'Ali realized from the first time, that the war techniques 
and firearms technology that he hoped, requires a series of advanced fortifications which are compatible with the development of modern weapons [32]. The innovation introduced into military architecture by Mehmet 'Ali is the regular designs of the external and internal lines of the buildings, and the types of the towers to be compatible with attack and defensive weapons. This new type of military architecture was called the bastion system, which were adopted with the new technological renovations by lowering its walls heights with more depth and building square towers instead of circular and semi-circular ones -Mamluk and Ottoman towers- and a new slope decline the outer walls and supported it by huge quantities of earth to be anti-missile cannons. The Pasha had applied this new architectural system, in the castle of the mountain (alGabal) ${ }^{(\mathrm{g})}$, which is one of most conspicuous archaeological structure of the Cairo. The fundamental function of new fort was the protection of the governance center of Egypt -the citadel of Salah al-Din- by cannon bombardment from eastern side [31]. Notable, this strategy is the same with the defense strategy of the Rumeli Hisar $1452[19,27]$. The fort is formed by four curtains $22.5 \mathrm{~m}$, flanked with four bastions irregularly shapes in the corners, fig. (5-a). The access is through an arched gate located on the NW side. The SE side contains a huge circular tower, fig. (5-b). Generally; the distance between bastions is variable, but they are regular or systematic and to some degree predictable. This distance depends on the location typography. Lawrence had told us to build $2 \times 4$ an bastion at $20 \mathrm{~m}$. intervals requires constructing approximately $140 \mathrm{~m}$. of curtain [16] and almost these are the same proportions used in the fortress of Mehmet 'Ali, where four bastions were built by two in each side, which swallows its length around 73 m., fig. (5-c) [5]. The optimal spacing between bastions would be between one half and one third the effective range of the principal defensive projectile weapons. This design is flexible for the maximum intensity of covering fire [16]. As mentioned; the organization of the fort in accordance with the new technique had a modern layout which was uncommon to the Egyptian fortifycation system before 1798, when the French have renovated the fort of Qaitbay in Rosetta [6] and in al-Gabal fort of Mehmet 'Ali [5]. The layout had met the defy of attackers, whose trying to be in closest point as possible to strike from the side and the curtain walls of the defensive positions by the parallel lines. These modifications were made to the defensive towers, due to the deficiency resulting from the narrow angle of view in the circular towers and consequently the narrow range of fire at the enemies in front of the fort. In other words, the obtuse corners and the threatening ribs of the bastion opened a greater field of vision to the cannons, fig. (5-d). The use of angled bastions to elim-inate the blind points was used for the first time in Egypt in Rasheed fort by the French architects. Depending on the comparative studies to the remaining castles in Eastern Europe that dated back to the Ottoman period, we find another evidence that proves the direct architectural impact of these ottoman castles on the architecture of Mehmet 'Ali in Egypt, especially since he had dealt with these castles directly during his war operations in Greece and other Ottoman states in Europe. The above investigation was a try to determine and follow the origins of bastion design which used in the forts of Mehmet 'Ali; the earliest example is the fort above al-Muqttam; the layout of the fort consists of a square area with four bastions in the corners; Some studies suggest that the origins of this planning are due to European influences in general and French in particular, as designed by Drofti and implemented by engineer Galice [5]. Another study indicates the Mamluk origin of this planning, as it is similar to the layout of Qaitbay castle in Alexandria, However, there is a big difference between the two layout sand could not be said that a Mamluk influence was effective in designing al-Muqttam fort as well as Rosetta castle, fig. (5-e) [6], after the French renovation in 1798 [31], or indicating to the star castles [1]. In general; the Ottoman models were not far from the Pasha's mind, however, when he planned his new army. As previous; he 
explicitly ordered his son Ibrahim Pasha to adopt the structure that Sultan Salim III had used in his own army [11]. Therefore, Mehmet 'Ali's mentality was affected by the castles and fortresses that existed in his hometown, when he chose the plans and reforms of his defenses by building his bastion fort on the top of the al-Muqttam mountain, fig. (5-b) opposite his seat of rule and other military architecture in Egypt. By reviewing the genesis of Mehmet 'Ali and learning about the common warfare systems that were used in his hometown, we can place our hands on the main influencer in his warfare buildings. There is no doubt that the rise of Mehmet 'Ali in the city of Kavala ${ }^{(\mathrm{h})}$ [33] had a great role in forming his personality and military vision, it was formed the mental image in his mind, where we find that this city since 1391 was one of the Ottoman provinces in Europe, where they built and repaired many defensive fortifications, which is difficult to detect rather than other architecture categories; due to the successive works over centuries by Byzantine, Venetians, and Ottomans as well [34]. The castle of Kavala is an impressive Ottoman fort in the northern city; its current building is mainly from the reconstruction of the Ottomans in 1425. Following the typography of the land, the defensive system girdled the mountain, and the walls were reinforced by bastions and circular towers. The perimeter is closed off by a transverse wall $449 \mathrm{~m}$. in length, which climbs a steep slope to the most inaccessible cliffs on the north side to a height of $64 \mathrm{~m}$., fig. (5-f) [35]. Here, the similarities between this Ottoman castle and Mehmet 'Ali's fort are clear to us in terms of choosing the location so that it defensively controls the city, as well as in terms of the ramp road, and to the use of the bastion system. In Balkan there are many remaining examples of Ottoman castles, especially in Albania; almost are identical to the scheme of Mehmet' Ali fort in Egypt. Such as the castle of 'Ali Pasha [36] in Butrint, fig. (5-g). There were another indirect impacts have participated in the formation of mentality of Mehmet 'Ali, such as the pra- ctical experience that formed many political and military concepts of Mehmet' Ali; those battles he fought in the Greek regions, and this direct contact with fortresses and Ottoman defenses controlled by the Greek revolutionaries [8]. As known, Mehmet' Ali's army had participate in several wars on European lands since 1824, for the Ottoman Sultan Mahmoud II, who requested the intervention of Mehmet' Ali's forces to assist Rashid Pasha's forces in controlling the Greek city of Mesolonghi. After the victory, the Egyptian forces headed to Morea, then the Egyptian army, led by Ibrahim Pasha, again took control of the Peloponnese and Athens and brought it back under Ottoman rule, but he was forced to stop because of the huge fortifications in Vergas [8]. We have a great example in the city of Mesolonghi or Fence of Mesolonghi, the city in which Ibrahim pasha fought himself and besieged its fortified fortress with the bastion system in 18251826, fig. $(5-i)^{(i)}$ [37]. The real practical experience which affected the choices of Mehmet 'Ali, was the Crete Island which was important station for the Egyptian army, that he seized it and ruled it for ten years (1830-1840). Of course, its fortifications were a source of influences on Mehmet' Ali's military constructions in Egypt, where the island includes several important examples that have been fortified by the bastion system, such as a fortress Candia (Heraklio). Which the Venetians improved on the ditch of the city by building enormous fortifications, most of which are still in place, including a giant wall, with 7 bastions, and a fortress in the harbor from 1212 to 1669 , fig. (5-j) [38], and the fortress of the city of Rethymno which dates back to the period of the rule of the Venetians 1204-1669.The bastion as a defensive system had represented in the walls of Chania also. This town fell into the hands of the Venetians in the mid- $13^{\text {th }}$ century, whose main priority was to defend and protect the city. From 1538 to 1549 an engineer named Sanmichieli was appointed to oversee the construction of new walls. The new fortifications, which also surrounded the port area, included a four-sided 
wall fortified by a moat, a counterscarp, heart-shaped bastions and ramparts. Mehmet 'Ali fought and ruled the Peloponnese region and signed a fortress in Palamidi ${ }^{(j)}$ [39] under his control, it consists of eight bastions and a long stairway slope and leads up to the fort. Here we can notice the great similarity between his castle in Cairo and between fortress Palamidi 1714 in Nafplio, the strategic location which control the Peloponnese, the moat and the slid road, fig. (5-k). In 1715 it was controlled by the Turks and remained under their control until 1822, when it was captured by the Greeks. It can be believed that the environment in which Muhammad Ali grew up and then the practical experiences in Greece and Anatolia that resulted indirect contact with the strengths and weaknesses
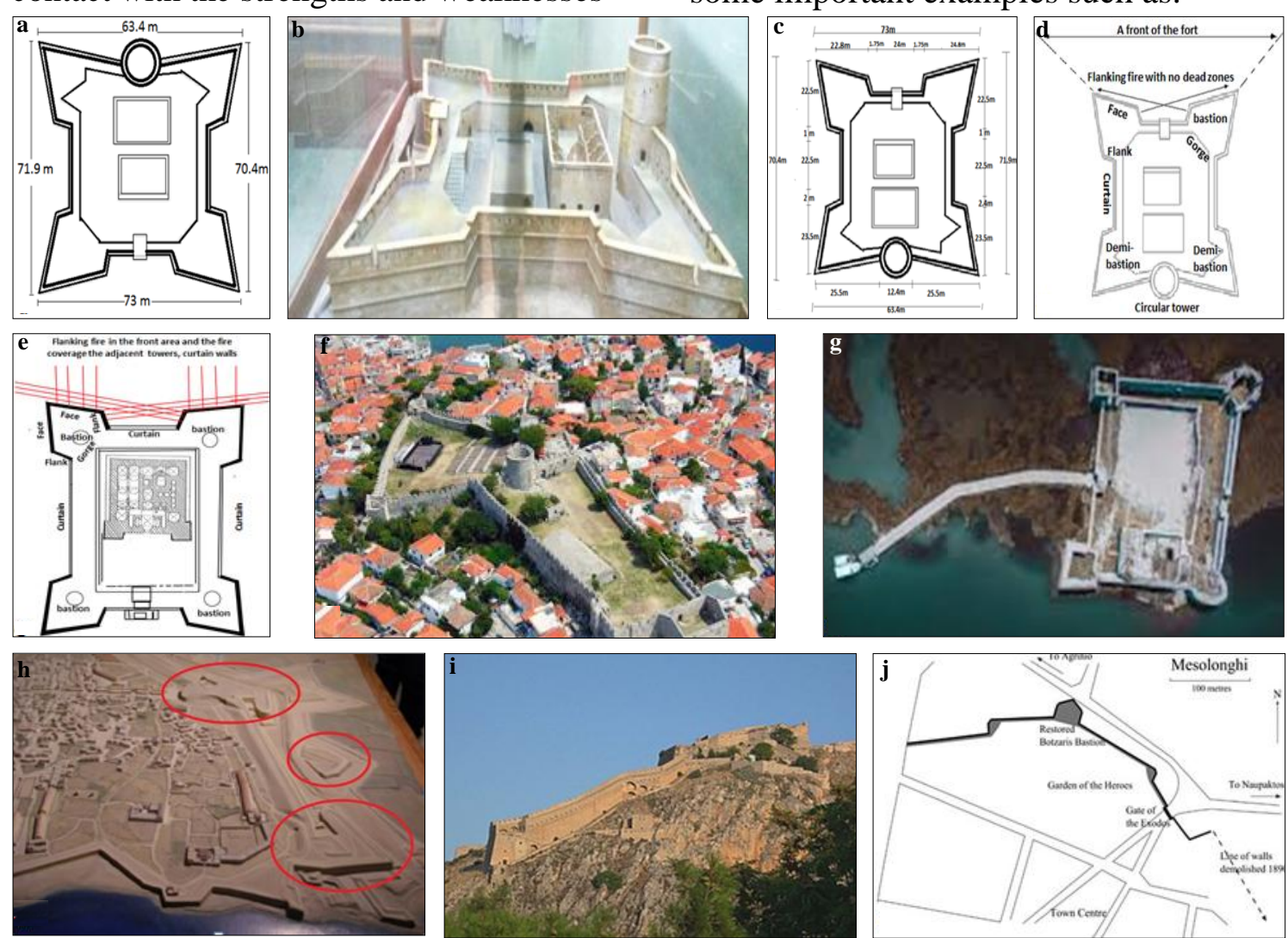

Figure (5) Shows a. the plan of Mehmet' Ali fort al-Gabal, $\underline{\mathbf{b}}$. 3D to the fort of Mehmet' Ali, Cairo, military museum in the citadel, $\underline{\mathbf{c}}$. the regular and systematic distance between bastions of Mehmet 'Ali alGabal fort, $\underline{\mathbf{d}}$. the bastion ribs and elements which achieved a perfect side protection and coverage and allows the defense of the gate, curtains and the circle tower of al-Muqttam fort (after, Mahfouze, 1999), e. the elements of angled bastions with loopholes from which gunners and artillerymen could fire and extend covering fire for the adjacent tower of Rosetta castle after 1798. (after, Darwish, 1991), f. shows the bastions of the Ottoman castle of Kavala city https://www.kastra.eu/castleen.php?kastro= kavala, g. shows aerial view of the castle of 'Ali pasha in Butrint, with bastions and curtains (after, Carvajal, 2018), h. the bastions of Mesolonghi fortress with the defensive bastion system (after, Kastrologos, 2012-2020) https://www.kastra.eu/castleen. php?kastro=mesologi, i. 3D. plan to the bastions of Heraklio castle (by the author), j. the ramp of Palamidi fortress-Nafplio Greece https://www. kastra. eu/castleen. php?kastro=palamidi 


\subsubsection{The arsenal fort at Rasel-Tin}

The arsenal fort at Rasel-Tin, which built on the ruins of an ancient fort, it was called by Lauber in a book describing Egypt called a battery [41]. The designs and plans for the construction project of the arsenal, by Sirzi Bey, were submitted in 1829 by Mehmet 'Ali, who approved it. Among these designs was the design of the fortress in the bastion style to defend the arsenal and the western port ${ }^{(\mathrm{k})}$, fig. (6) [42].
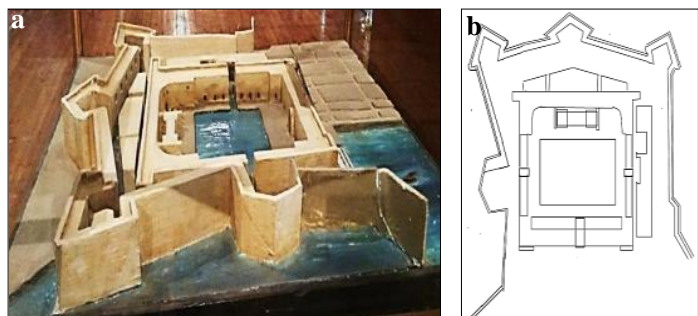

Figure (6) Shows a. shows 3D design the arsenal fort at Ras El-Tin built during Mehmet 'Ali reign to protect the harbor. (Military museum in the citadel, Cairo), $\underline{\mathbf{b}}$. plan of the arsenal fort at Ras El-Tin (by the author)

\subsubsection{The Fort of Kousta pasha}

The fort of Kousta Pasha east of Alexandria in Abu Qir to defend Alexandria, is considered one of the most important examples of military architecture in the era of Mehmet' Ali, as it dates back to the year 1840, based on the orders of Mehmet' Ali to the ruler of Abu Qir Mehmet Kousa Pasha, which was named after with his name [43]. The layout of fort is a pendagonal bastion concloud two semi-bastions flanking the entrance, fig. (7).

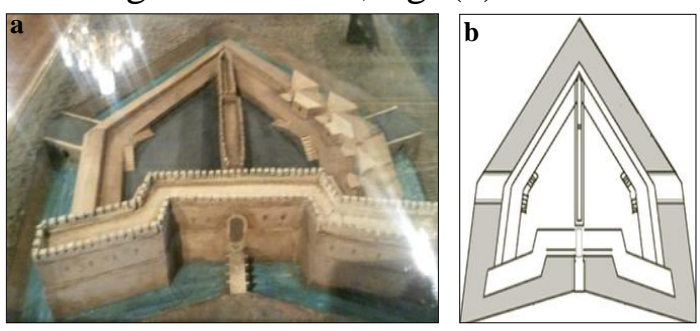

Figure (7) Shows a. 3D design to Kousta Pasha fortressin Abu Keir Alexandria, (Military museum in the citadel, Cairo), $\underline{\mathbf{b}}$. plan of the Kousta Pasha fortress (by the author)

\subsubsection{The fort of El Tawfekeya}

The fort of El Tawfekeya, it was known also by "El Shaheeneya" fort, it is lies in the west of Abu Keir. It was erected in
Khedive Ismail period and was completed by Khedive Tawfeek in the same design of Mehmet 'Ali's fortifications such as the fort of Kousta Pasha. The layout of fort is a pendagonal bastion concloud two semi-bastions flanking the entrance, fig. (8-a, b). Also in Al 'Alameya fort in Abu Qir was designed with the same external pentagonal layout with the two semi-bastions to protect the gate and the external walls, fig. (8-c, d).
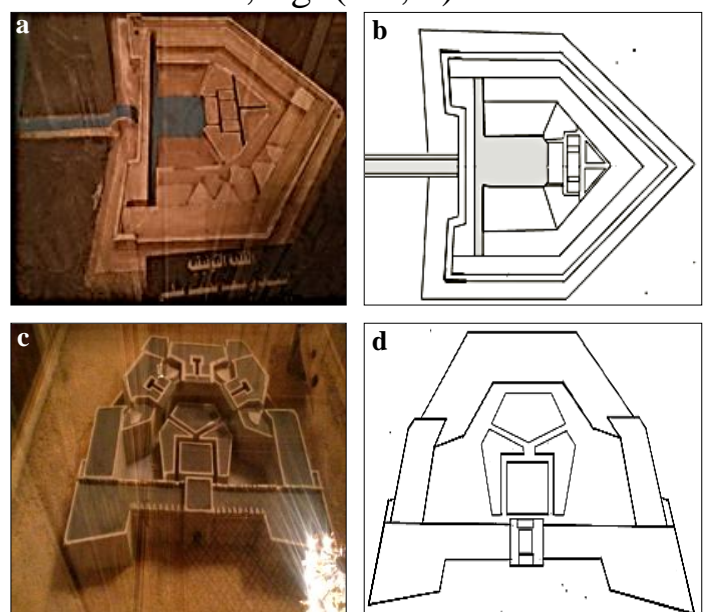

Figure (8) Shows a. the layout pentagonal design of Al Tawfekeya fort, $\underline{\mathbf{b}}$. the layout of $\mathrm{Al}$ 'Alameya fortress (by the author).

\subsubsection{Al Max fort}

Al Max fort; the military architect have replaced the known bastions by using the exterior walls designed with specific angles and with the same elements of the bastionFace, flank and gorge- that perform the function of protecting the external walls and overcoming the dead areas resulting from the ancient designs of the towers, fig. (9).

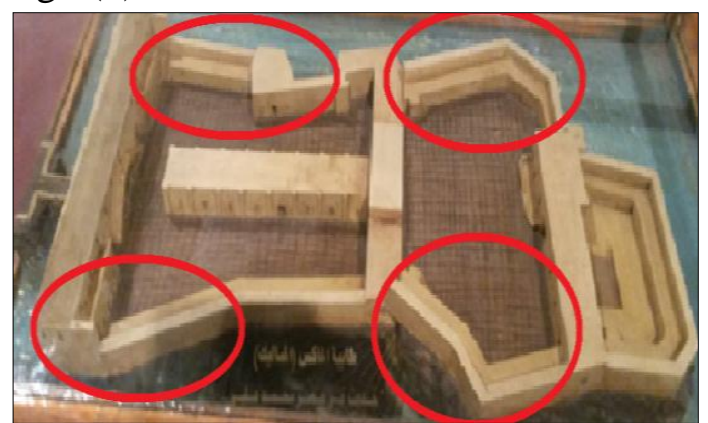

Figure (8) Shows 3D layout and angled Curtin walls of El Max fortress from Mamluks reign and renewed during Mehmet 'Ali's reign. (Military museum in the citadel, Cairo). 


\section{Typology of the Angled Bastions of Mehemt 'Ali's Forts}

With the development of explosive shells and powerful artillery in $18-19^{\text {th }}$ centuries, the complexes star forts were replaced by robust and simpler polygonal forts, exactly such as the forts of Mehmet 'Ali's reign. By analyzing the remains forts of Mehmet 'Ali in Egypt, there are different types of angled bastions can be found and will tracing in tab. (1)

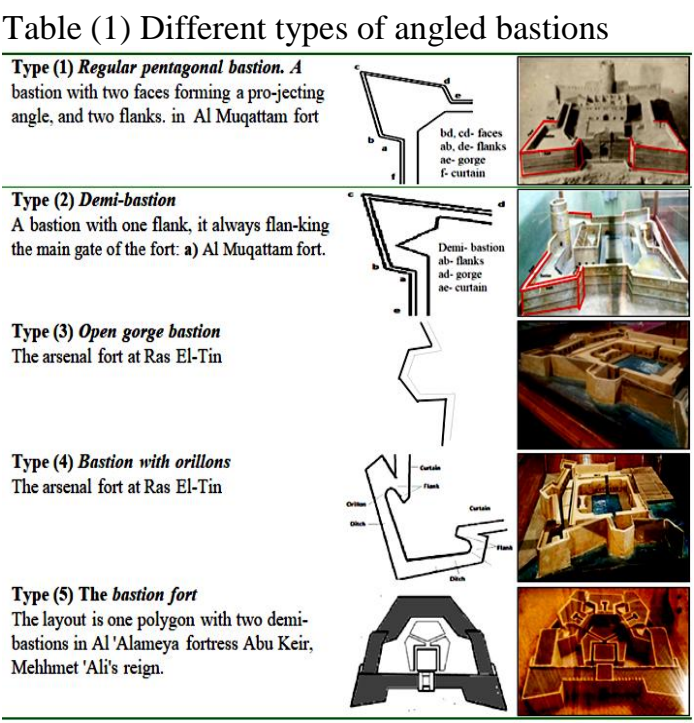

\section{Results}

The main question of the study was the origins of the bastion element which separated in large scale as a European influence from the end of $18^{\text {th }}$ and the first decade of $19^{\text {th }}$ centuries in Egyptian military architecture and what the channels of these influences are?; to answer this question it must be depend on the literature sources to trace the universal features which maintains in Egypt. There are two theories about the origins of bastion design; Italian origins and Ottoman origins. By tracing the objects universal features of Ottoman defensive architecture in castles of Jalal al-Din, Kilid Bar and Kasr al-Tina (14-15 ${ }^{\text {th }}$ centuries); the Ottoman military architects also influenced the Italian engineers in the scientific and geometric layout of a fortification. So the Ottoman bastion had affected indirectly the bastion system of Mehmet 'Ali by Italian and French engineers. -There new organization and developments in the Egyptian army were imported throw four channels;

*) The emergence of Mehmet 'Ali's in Europe.

*) The supporting of the foreign education and economic and military expansion.

*) Mehmet 'Ali recruited the scientific and military cadres to seek their services in establishing military.

*) The real experience of Mehmet 'Ali in the Ottoman army and the practical experience battles he fought in the Greek regions, and this direct contact with fortresses and Ottoman defenses controlled by the Greek revolutionaries in Mesolonghi, Certe, Peloponnese and Anatolia have been formed many political and military concepts of the Pasha and represented direct and indirect influences on his choices.

The distribution of the bastions of the Algabal castle were followed the same rules that were followed in the European Bastion system in Italy and France which had defined in sources which have told us to build $2 \times 4$ an bastion at $20 \mathrm{~m}$. intervals requires constructing approximately 140 $\mathrm{m}$. of curtain and almost these are the same proportions used in the fortress of Mehmet 'Ali, where four bastions were built by two in each side, which swallows its length around $73 \mathrm{~m}$. There are different types of angled bastions can be found and will tracing in tab. (1).

\section{Discussion}

After Mehmet 'Ali assumed the reign of Egypt, both western powers tried to attract them in order to achieve their benefits, as he had the legitimacy it gained from the approval of the Ottoman Sultan, as well as from the popular support of scholars. France supported him so that England would not be unique to him alone. As for the latter, she made a spearhead to use it, and its relationship with the Ottoman Empire pushed it to help it eliminate the forces with a religious background in Arabic provinces and the Greek Revolution in Peloponnesus, which almost eliminated the Ottoman 
presence in Europe had it not been for Mehmet 'Ali at the behest of the England to support the Ottoman Empire. In order to devote itself to the Russian conflict to prevent it from forming bases on the Mediterranean Sea. There is no doubt that the style of the Egyptian army in the reign of Mehmet 'Aliwas organized on the same style of the Ottoman army in the reign of Sultan Selim III, but the forts designs were influenced by two motives; the engineering necessities of the gunpowder age and by the architectural innovations rooted in Italy and seen in the trace italienne which was originate from Ottoman architects designers in castles of Jalal al-Din, Kilid Bar and Kasr al-Tina. So, it could be said that the design of angled bastion influenced by the ottoman military architects. Thus, the angled bastions which were uncommon in Egyptian fortresses before 1798, were derives its origins from the Ottoman sources and Italian elements by French architects and its first examples were in the French additions at Rosetta castle and was in response to new developments in the artillery. There were a dramatic changes in the architectural layouts of Mehmet 'Ali's reign and prevalent of using of the angled bastions, to eliminate the dead zones or blind areas, because the bastions allowed for a clear lines or vision of fire to all outer parts from the flanks. Obviously, that angled bastions were simpler than the complex star forts of previous periods in Europe. These new military organizations and architectural developments were imported to Egypt throw four indirect channels: The first; there is no doubt that the emergence or the European raise of Mehmet 'Ali Pasha was the main indirect impact in forming his vision for the country he dreams of forming and of course the formation of its various institutions. The second; the policies of the Pasha; his reign is characterized by the active recruitment of foreigners and supporting the foreign education and economic and military expansion. He did not entirely imitate European design or architecture; however, instead he blended Ottoman and European styles to assert a uniqueness, independence, and cosmopolitanism. The third; Mehmet 'Ali recruited the scientific and military cadres to seek their services in establishing military, engineering and medical schools while serving his reform policies in Egypt, such as Suleiman Pasha the Frenchman, General Boyerand Galis. The fourth; the field experiences of the army of Mehmet 'Ali, led by his son Ibrahim in the European lands, in which he fought many battles to support the Ottoman Empire in the war against the Greek Revolution in Crete and al-Morea, which resulted in the control of Mehmet 'Ali over these areas. This gave him the opportunity to contact defensive fortifications on European lands and deal with the tactics of European armies, especially the navy, the Battle of Navarino (1827).

\section{Conclusion}

It could access the architectural references that greatly influenced, directly and indirectly, the designs of military architecture that Mohamed 'Ali established in Egypt. We find the first impact were the concepts and will of the Pasha in forming a strong European-style army depends on it in protecting its gains. Thanks to his genesis which helped to establish these concepts and form his vision. Without doubt that the previous models have many similar elements in the Mehmet 'Ali castles in Cairo and Alexandria, which confirms the influence of these Ottoman castles on the military architecture dating back to his era. Mehmet 'Ali's joining of the Ottoman army helped to understand many of the rules that must be met in the buildings of the military structure of the new army, where he saw many castles and accompaniment to military technology in Kavala where he grew up, and in Mesolonghi and in the castles of Chania, Heraklio and Rethymno on the island of Crete that Mehmet 'Ali ruled for ten years (1830-1840) under the cloak of the Ottoman Empire. In addition to those scientific missions that he sent to Europe, especially France and Italy since 1822, which resulted in the preparation of many military and scientific cadres that contributed to the development of military and industrial performance in the era of Mehmet 'Ali, where they worked in many areas besides foreign cadres and expertise that he brought in to benefit from their practical experiences in the army. The most common defensive towers before $19^{\text {th }}$ century in Egypt 
were rectangular, square or circular in plan. These forms are roomy, providing the optimal space for defenders and canons given their dimensions. However, there is an area of blind ground which protects the attackers in front of previous forms of bastions. Geometrically, pentagonal "break water" bastions were easily defended by fire from curtain walls because there is no blind or dead ground in front or beside of them, in addition, the former would crowd and limit the number of defenders depending on bastion's militarily effective points. By analyzing the typology of the angled bastions of Mehmet 'Ali; it have been erected on five types have classified in table (1).

\section{Endnotes}

(a) Sultan Selim III was undertaken a program of westernization and whose reign felt the intellectual and political ferment created by the French Revolution.

(b) It is very clear that the Ottoman influences included the basic composition of the army of Mehmet 'Ali, who had decided to choose the Ottoman model for the formation of army divisions, which started with six battalions - Orta - each with 800 Uttrah soldiers, then the number of these battalions increased to become units - become units - provinces - each with five battalions. By this we can understand that Muhammad Ali chose the model of the Ottoman army with its units and ranks as well as its defense strategies and military fortifications.

(c) A star fort, or trace italienne, is a fortification in the style that evolved in the period of gunpowder when cannon dominated the field of battles. It's first seen was in Italy probably in the mid $15^{\text {th }}$ century. In contrast, the star fortress was a flat structure composed of many triangular or lozenge shaped bastions designed to cover each other, and a (typically dry) ditch. Star fortifications were further developed in the late fifteenth and early $16^{\text {th }}$ centuries primarily in response to the French invasion of the Italian peninsula.

(d) A trace italienne (a term derived from French, meaning Italian outline); is a bastion fort evolved during the period of early modern of gunpowder, when the artillery (cannon) had dominated the wars and were combined with the star fort. This style of fortification that became prevalent after about 1500 which involved the heavy use of geometric design and employed angled bastions at all corners and some in between.

(e) Francesco di Giorgio Martini was an Italian engineer, architect, painter and writer, he was born in Siena. As a military architect, he executed architectural designs and built the early star-shaped fortifications for the Duke of Urbino Federico da Montefeltro. His book is deal with the ideal protection city, overly controlled within polygonal geometries memorial of the star fort and the wedgeshaped bastions have been innovated.

(f) Michele Sanmicheli was a Venetian military architect, he was born in San Michele (1484-1559), he designed many fortifications to the Venetian Empire in Italy, Venice, Crete, Corfu, Candia and Verona. By 1527 he worked on the cannon-resistant city gates and had transformed the fortifications of the city of Verona to the new fortification system of angled bastions in corners.

(g) The castle of Muhammad Ali or al-Hesn, which was formerly known as the Tabiah of Napoleon, until the error was corrected and restored to its origin to Muhammad Ali's reign

(h) Kavala was a part of Rumelia Eyalet in ottoman period, now locate in Greek province of Macedonia.

(i) Fort or Fence of Missolonghi in the west of Greece on the Patras Gulf [37].

(j) Palamidi (Gr, П $\alpha \lambda \alpha \mu \eta \dot{\delta} \delta$ ) the finest example of Venetian fortification in Greece, was built in 1714 [39]

(k) 1. Al-Fanar Tabiya 2. Al-Fanar small cousin 3.The dirt pomegranate (semicircular) is located in the loop of fish in Anfushi 4. The new dressing Tabia 5. Tabia Alatta 6. Al-Zafar castle 7. Charred cob 8. Tabia obelisk of Pharaoh 9 . The cemetery of the ancient tombs of the Jews 10 . The Jewish cemetery 11.Tabia Tower Chain 12. Tabia Bab Sharqi. 


\section{References}

[1] Al-Rajabi. K. (1997). Tarikh alwazir muhamade ali Pasha (History of Minister Muhammad Ali Pasha), Dar alafaq alearabia, Cairo.

[2] Al-Jabarti, A. (1988). 'Ajayibalathar fi altarajum wal'akhbar (the wonders of antiquities in biographies and news), $3 \mathrm{Vol}_{\text {s., }}$ Book Egyptian Organization, Cairo.

[3] Wiet, G. (1959). Mohammed Ali et les beaux-arts, Société royale détudes historiques, Dar Al Maaref, Cairo.

[4] Mantell, A., (2010). Dictionary of military technical terms: English-Arabic, Arabic-English, Vol. 1, Kessinger Pub., Montana USA, 2010.

[5] Mahfouz, A., (1999). Al 'Emaer Al Hrbia fi Aser Muhammad Ali fi Aser Muhammad Ali fi madinat Al- Kaherah (The military architecture of Muhammad Ali era in Cairo), MA, Islamic Archaeology dept., Faculty of Archaeology, Cairo Univ., Egypt.

[6] Darwish. M., (1991). Al-aistihkamat alharbiat bi madinat Rashid fi al asr Almamluki hata asr Muhamad Ali (the Military fortifications of Rosetta city form Mamluk period to Muhamad Ali's reign), Ph.D., Islamic Archaeology dept. Faculty of Archaeology, Cairo Univ., Egypt.

[7] Hamzah, D. (2007). Nineteenth- century Egypt as dynastic locus of universality, Comparative Studies of South Asia, Africa and the Middle East, Vol. 27 (1), pp.62-82.

[8] Saleh, K. (2010). Anatolian operation of Kavali Mehmet Ali pasha and the battle of Konya, J. of Faculty of Letters, Seljuk Univ., Vol. 23, pp. 145-158.

[9] Kocaoglu, M. (2011). The revolt of cavallan Mehmet Ali pasha (18311841). http://dergiler.ankara.edu.tr/der giler/19/1151/13518.pdf, s. 211 (8-112011).

[10] Fahmy, K., (1998). The era of Muhammad Ali Pasha 1805-1848, in: Daly, M. (ed.) The Cambridge History of Egypt, Cambridge Univ. Press, pp. 139-179.
[11] Dodwell, H. (1967). The founder of modern Egypt, Cambridge Univ. press, Cambridge.

[12] Pradines, S, (2019). Maintien de la paixet protection du territoire. Le réseaufortifié des Ottomans en Egypte, in: Eychenne, M., Pradines, S. \& Zouache, A. (eds.) Guerre et Paixdans le Proche-Orient Médiéval, Xe-XVe siècles. Histoire, archeology et anthro-pologie, IFAO/IFPO, Cairo, pp. 251-287.

[13] Lawrence, A. (1979). Greek aims in fortification, Oxford Univ. Press, Oxford.

[14] Pepper, S. (2000). Ottoman military architecture, city walls, in: Tracy. J. (ed.) The Urban Enceinte in Global Perspective, $1^{\text {st }}$ ed., Cambridge Univ. press, Edinburgh 2000, pp. 290- 310.

[15] Manolis. P., (2010). Types of castle and the history of castles, star forts, http://www.castle sandmanorhouses. com/types_10_star.htm (8-11-2019)

[16] Keeley, L. (2007). Baffles and bastions: The universal features of fortifications, J. of Archaeological Research, Vol. 15 (1), pp. 55-95.

[17] Ulivieri, D. (2014). Fortezza vecchia in Livorno, Nexus Netw J., Vol. 16: 675-697.

[18] Robert, T. (2013). Fortification renaissance: the Roman origins of the trace italienne, MA Arts, Univ. of North Texas, Texas.

[19] Ozguven, H., (2014). Early modern military architecture in the Ottoman empire, Nexus Network J., Vol. 16, pp. 737-749.

[20] Hyde, J. (2015). Elementary principles of fortification, Lewis and Son Press, London.

[21] Catharina, L. \& Hugo. S. (2012). Worthy efforts: Attitudes to work and workers in pre-industrial Europe, Brill NV, Leiden.

[22] Geoffrey, P. (1988). The military revolution: Military innovation and the rise of the west, 1500-1800, $2^{\text {nd }}$ ed., Cambridge Univ. Press, London. 
[23] Nekolaus, P. (1963). An outline of European architecture, $7^{\text {th }}$ ed., Penguin Books, London.

[24] Lynn, W. (1969). Science, technology, and warfare (1400-1700), in: Monte, D. (ed), The Military History Symposium, History and the association of graduates dept., United States Air Force Academy, U.S. Government Printing Office, Washington. DC., pp. 3-25

[25] Jose, C. (1999). The castle of Ali Pasha at Butrint, in: Inge, L. (ed) The Archaeology and Histories of an Ionian town (Butrint 4), Oxbow books, Butrint, pp. 289-309.

[26] Ozguven, H., (2014). Early modern military architecture in the Ottoman Empire, Nexus Network J., Vol. 16, (3), pp. 27-38.

[27] Erișmiş, M., (2013). Rumeli fortress from the perspective of architecture history, Frontiers of Architectural Research, Vol. 2 (4), pp. 409-419.

[28] David, N. (2009). Saracen strongholds: 1100-1500, the central and eastern Islamic lands, $1^{\text {st }}$ ed., Osprey Pub., NY.

[29] Chisholm, H. (1911). Sanmichele, Michele, in: Chisholm, H. (ed), Encyclopedia Britannica, $11^{\text {th }}$ ed., Vol. 24, Cambridge Univ. Press, London, pp. 154-155.

[30] Lynn. J. (2018). The trace Italienne and the growth of armies: The French case, J. of Military History, Vol. 55 (3), pp. 169-200.

[31] Alasmey, M. (1924). Qaleat Muhamad Aali laa Qaleat Nabliun (Muhammad Ali castle, not Napoleon castle), Egyptian General Organization of Books, Cairo.

[32] Colvin, P. (1998). Muhammad Ali pasha, the great exhibition of 1851 ,
School of Oriental and African Studies J., Vol. 33 (3), pp. 249-259.

[33] Robison, S. (1942). History of naval tactics from 1530 to 1930: The evoution of tactical maxims, $1^{\text {st }}$ ed., U.S., Naval Institute, Annapolis, USA.

[34] Ameen, A. (2020). The Ottoman bedestens in Greece, Shedet, Vol. 7, pp. 115-144.

[35] Manolis, P. (2014). Kastrologos, Greek castles. http://www.castlesandm anorhouses.com/types_10_star.htm (10-5-2019)

[36] Crowson, A. (2007). Venetian Butrint, Butrint Foundation, London.

[37] Andrew, K. (2006). Castles of the Morea, Princeton, American School of Classical Studies, Athens.

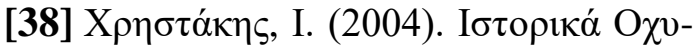

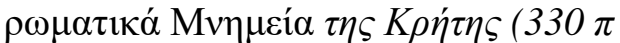

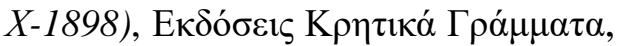
Crete.

[39] Brooks, A. (2019). The fortifications of Nafplioi, Aetos Press, UK.

[40] Mubarak, A. (1997). Al- khitat attaufììya al-ğadīda li-Miṣr al-Qāhira wa-mudunihā wa-bilādihā al-qadīma (New compromise plans for Egypt, Cairo and its cities), Vol. 7, Egyptian General Organization of Books, Cairo.

[41] Tuson, O. (2015). Alsanayie wal madaris alharbia fi ahd muhamad ali pasha (Works and military schools during the reign of Muhammad Ali Pasha), Hindawi Foundation for Education and Culture, Cairo.

[42] Masrot, A. (1984). Egypt in the reign of Muhammad Ali, Cambridge Univ. Press, Cambridge.

[43] Sharaf Eldin, Sh. (2013). Abu Qir fortresses as vital assets for tourism motivation and community development, J. of Heritage Conservation, Vol. 34, pp. 48-56. 